FIEDLER Malte,

Carl Friedrich Gauss Faculty, Institute of Marketing, Technische Universität Braunschweig Universitätsplatz 2, 38106 Braunschweig, Germany

E-mail: malte.fiedler@tu-braunschweig.de
KISSLING Martin,

Carl Friedrich Gauss Faculty, Institute of Marketing, Technische Universität Braunschweig Universitätsplatz 2, 38106 Braunschweig, Germany

E-mail:m.kissling@tu-braunschweig.de

\title{
FAKE REVIEWS
}

\section{IN E-COMMERCE MARKETING}

Online reviews have shown to be a significant source of information in the purchase decision process. The deceptive manipulation of reviews has become a substantial challenge for both the research and e-commerce industry. In this regard, scholars made the first attempts to analyze the motives and causes of these so-called fake reviews. However, there is still a lack of a comprehensive and differentiated overview on this topic. The present article seeks to fill this gap by reviewing the current state of research on userrelated and supplier-related causes as well as the effects of fake reviews from the perspective of the recipient, supplier, and platform. Therefore, we contribute by deriving key research gaps.

Keywords: fake reviews, online reviews, online recommendation system, product reviews, manipulation, e-commerce

Фидлер М., Кислинг М. Фейковые отзывы в маркетинге в электронной торговле. Онлайн-отзывы стали важным источником информации в процессе принятия решения о покупке. Манипулирование отзывами - серьезный вызов как для исследователей, так и для специиалистов электронной индустрии. В связи с этим ученье сделали первые попытки проанализировать мотивы и причины этой ситуации. Однако всестороннего и дифференцированного обзора все еще не хватает. Эта статья имеет целью заполнить этот пробел путем обзора текущего состояния исследования причин, связанных с пользователем и поставщиком, а также следствий ложных отзывов с точки зрения получателя и платформы.

Ключевые слова: ложные отзывы, онлайн-отзывы, система рекомендаций в Интернете, отзывы о товаре, манипулирование, электронная торговля.

Background. The Internet has changed the process of searching for information and, thus, has shaped our shopping behavior [1]. It is no longer just a place of knowledge but offers an interactive platform for any purpose of exchanging individual experience with products or services [2]. Consequently, suppliers no longer retain exclusive authority over the offering of information. Through the interactive nature of the web, consumers are also capable of providing information, and thus the information asymmetry is reduced $[3 ; 4]$.

Consumer-based information in the shape of online reviews is valuable for potential customers and therefore represents an essential element in the buying decision process [5-7]. Against this backdrop, the increasing

(C) Fiedler M., Kissling M., 2020

ISSN 1727-9313. ВIСНИК КНТЕУ. 2020. 
relevance for scholars and practitioners can be explained [8]. Platforms like Yelp.com or Tripadvisor.com even base their whole business model on online reviews [8].

The internet-caused change not only holds chances but also carries potential risks. An increasing number of fraudulent information is being spread online. Notably, this also affects online reviews [9]. So-called fake reviews are being produced and distributed from various protagonists and often deployed intentionally. Occasionally, organizations offer the drafting of fabricated or bogus reviews as a paid service [10]. According to the Times, almost every third online review on TripAdvisor was found to be forged [11].

A high level of complexity characterizes the causes and impacts of fake reviews. Consequently, they can be considered a considerable challenge both for research [12] and the e-commerce industry. Whereas motives and effects of online reviews, in general, have been investigated comprehensively [1], differentiated research on fake reviews is scarce.

The aim. This paper aims to fill this gap by systematically reflecting upon supplier- and user-related causes of fake reviews as well as exploring their consequences from three perspectives: (1) the recipient and (2) the product or service supplier and (3) the review platform. By deriving key research gaps, we finally reveal potential areas of future research.

Materials and methods. As presented, this paper aims to collate present findings in the area of fake reviews. For this purpose, the authors conducted a systematic literature review among several databases. After narrowing down the search outcome regarding the causes and consequences of fabricated online reviews, we completed the results by manual follow-up research.

Results. Overview and Classification of Fake Reviews. Fake reviews, also called deceptive or fraudulent reviews [8], are reviews of products or services that intentionally aim to delude the reader through an authentic manner [13]. Choi, Mattila, van Hoof \& Quadri-Felitti (2017) define the term "fake reviews" as being written by users who pretend to be consumers without ever having used the product or service. Fake reviews intend to affect readers' buying decisions [14]. In this light, they are also described as deceiving or fictitious "opinion spam" $[3 ; 9 ; 13 ; 15 ; 16]$.

Fake reviews can be subordinated to electronic word-of-mouth (eWOM). By transferring traditional word-of-mouth to the internet, eWOM accomplishes to overcome conventional boundaries due to the advantages of modern IT. Hence, a high range of messages can be achieved [4]. Thus, it can affect consumer behavior significantly [7]. In the context of eWOM, online reviews, in general, are considered the most potent source of information for consumers $[4 ; 14]$. Under certain circumstances, consumers give stronger weightings to online reviews compared to their own assessment [4; 17]. Fake reviews attempt to make use of this fact and thus manipulate the consumers' purchase decisions [18].

Three forms of valence are allocated to fake reviews: negative, neutral, and positive. Negative reviews have a more substantial impact on the assessment and, thus, on the purchase decision [19]. Whereas positive reviews 
might create the impression of being disseminated by the supplier itself, they subsequently appear less trustworthy [7]. However, positive fake reviews occur most frequently [10] since negative statements are more likely to lead to legal action as a defense. The New York Times has revealed that the authors initialize a high share of book reviews on amazon.com themselves [20].

Despite detailed research in the area of eWOM and online reviews, differentiated investigations of fake reviews are still rare. Most scholars focus on contributing to the identification of counterfeit reviews [9], which often implies the consideration of linguistic aspects of the review content, such as the use of specific words or phrases [18]. However, research on the causes and effects of fake reviews is fragmented. Hence, this paper strives to fill this gap by aggregating and systematizing present findings.

Causes of fake reviews. The incidence of fake reviews is determined by various factors. In general, supplier- and user-based causes can be distinguished, depending on either supplier or private users of products or services induce fake reviews. The following section describes central findings on the causes of fake reviews with regards to those two perspectives.

Supplier-related causes of fake reviews:

Current findings. In essence, supplier-related reasons for fake reviews are mostly based on the consumers' growing tendency to resort to online reviews to prepare for a purchase decision [3]. As a matter of fact, this puts pressure on suppliers to reach and maintain good overall ratings of their offerings [5] and motivates them to initiate fake reviews. Significantly, distinct attributes of present reviews need to be considered. In that respect, Zablocki, Schlegelmilch \& Houston (2019) suggest three key characteristics: valence, volume, and variance of reviews [19]. Valence refers to the rating's nature, which is either negative, neutral, or positive. Suppliers with rather poor reviews strive for an improvement of their overall ratings by inducing favorable reviews [21]. The volume describes the total number of reviews for a specific offer [19]. However, a large number of reviews reduce the impact of each additional review [21]. On the contrary, single reviews carry even more weight when only a few reviews exist. The variance refers to the spread from negative to positive reviews. High variance negatively affects the customer's purchase decision [19]. Consequently, the influence of online reviews on the consumer's choice is strongly affected by the reviews' valence, volume, and variance. Therefore, these attributes determine the value of positive fabricated reviews.

In contrast, however, scholars show motives that lead to the initiation of negative fake reviews. Competitors might benefit from disseminating forged negative reviews on rivals' products [22]. Nevertheless, this only applies if consumers find appropriate substitutes for the offer.

Identified research gaps. In the first place, we suggest focusing on suppliers that draft fake reviews. The type and character of the supplier seem to play an important role. For instance, previous research points out that retail 
chains induce less fake reviews compared to independents [21]. A possible reason might be that their revenue less strongly depends on their ratings [21]. Additionally, the motivation for inducing fake reviews can arise from financial difficulties and thus be a result of desperation. Therefore, future research should examine to what extent a company's commercial success (or failure) determines the initiation of fake reviews.

Another motive that hasn't been put much effort into in current research yet is self-presentation. Many offers are strongly linked to the supplier's identity. Thus, negative reviews can be perceived as an assault on the supplier's self-concept. A possibly resulting betterment through specific actions can be referred to as impression motivation [23]. Future research should examine how these motives affect the intention to induce forged reviews.

Among some product categories, fabricated reviews seem more likely to occur (e. g. books or services). This fact indicates that the effect of motives to fabricate reviews differs depending on the type of product. In this light, offerings can be allocated to three particular qualities of goods: search, experience, and credence (or confidence) goods [24]. While individuals can assess search goods before a purchase and experience goods after buying a product or service, it is nearly impossible to assess credence goods at all. Thus, suppliers of experience or credence goods, in particular, can benefit from positive fake reviews. An empirical study could prove the hypothesis that fake reviews appear more often among these two qualities of goods than for search goods. Further, future studies might demonstrate differences concerning the motives of fake reviews in the context of all three different types of products.

User-related causes of fake reviews

Current findings. Even users induce fake reviews. Among user-related causes of counterfeit reviews, first and foremost motives from individuals need to be understood. Against this backdrop, Blank \& Reisdorf (2012) identified the so-called 4Fs with regards to the motivation of producing fake reviews: fame, fortune, fun, and fulfillment. Individuals write online reviews to increase their social recognition, to gain personal benefits, to preserve others from harm or loss, and to maintain a better quality assurance [25].

The reasons for fabricating fake reviews differ in some ways from each other. In the following, the paper considers dissatisfaction, of the one part, and benefits of economical or personal nature, of the other part. Dissatisfaction describes a negative user experience about a product or an organization. A high level of frustration can lead to negative ratings [8]. Consequently, the customers reciprocate perceived unfairness with an equally unjust reaction, or in their eyes pay like with like. This need is often satisfied by the fabrication of intentionally false online reviews.

Beyond that, the research identifies users who see themselves as a kind of brand managers. Those customers are characterized by high brand loyalty and, thus, aim to contribute to the suppliers' success by publishing positive online reviews without ever having purchased the product or service [8]. 
Furthermore, personal benefits tempt individuals to produce fake reviews. Those are mostly based on specific incentives from the supplier. For instance, organizations provide vouchers or gifts in return to the fabrication of reviews $[3,26]$. Individuals are motivated by such benefits to disseminate reviews without having made use of the corresponding offers. The effects are similar in the case of distinct awards that users receive on a platform for writing a specific (high) number of reviews. Such an award leads to a displayable status that as well can be seen as a source of social recognition.

Identified research gaps. Prior research on user-related causes merely focuses on drivers of writing fake reviews. Apart from that, also user-related barriers exist. The creation of fake reviews represents a form of immoral conduct. Therefore, the individual moral attitude could keep users from forging online reviews.

Furthermore, prevailing circumstances could alleviate user-side drivers. In this context, studies could examine, if a strong loyalty towards the offering brand or a strong empathy towards the supplier could keep individuals from creating fake reviews, despite any offered incentives. This investigation should also be assessed regarding the relationship with the platform since users might refrain from contaminating a platform that they henceforth want to make use of themselves.

Consequences of Fake Reviews

User-related consequences of fake reviews

Current findings. Fake reviews influence the behavior of online recommendation system users. These can be differentiated into passive and active users. While active users actively write reviews, passive users just inform themselves by reading them. Fake reviews reduce the value of all other reviews. Therefore, passive users adjust their inferences on the base of reviews. They discount the provided information in the knowledge of fake reviews existence [3].

Active users adjust their behavior due to fake reviews, too. Fake reviews can be seen as unfair behavior towards the reviewed supplier. If users are aware of such discriminatory behavior, this can cause positive reactions towards the supplier's brands. For example, the user might feel empathy for the supplier, which in turn might higher their willingness-to-pay or their recommendation intentions [27]. Some active users even try to protect the supplier and to prevent him from online review abuse and provide so-called watch-dog comments [28]. They comment on potential fake reviews and doubt their credibility and try to refute the assertions in fake reviews. Thus, they check online reviews and attempt to save passive users from abuse.

Identified research gaps. Beyond the provided insights, there are more effects on the behavior of active and passive users. For example, it should be tested, how prior experience with fake reviews influence how users deal with fake reviews. It might be that users not only discount the information provided [3], but adjust their searching behavior per se. Some online shoppers search for products by filtering for minimum ratings. Fake reviews can impact the filtering results substantially. Due to fake reviews, it might be that the rating is too low, and interesting results are filtered out. This point might be relevant

ISSN 1727-9313. ВІСНИК КНТЕУ. 2020. № $2=81$ 
for the optimal design of webshops. Thus, future research should focus on whether and how much fake reviews impair user search behavior.

Some active users post watch-dog comments [28], to aid the victims of fake reviews [27]. Nevertheless, the determinants of these watchdog comments remain unclear. It might be that a transparent and open communication by the firm encourages the brand community to comment doubtful reviews.

Plattform-related consequences of fake reviews

Current findings. The Internet, in general, and review platforms in particular offer the potential to reduce or even eliminate the information asymmetry between buyers and sellers [29]. Thereby, review systems increase the efficiency of the market, improve the allocation of resources, and higher the fairness between market subjects. Fake reviews decrease the information value and the credibility of review platforms [30]. The possibility of fake reviews causes consumers' mistrust [22] and reduces the value of real reviews [31]. At the extreme, this can lead to the obsolescence of review platforms; in any case, it lowers the overall value of review platforms [3].

In light of the presented adverse effects, and the increasing concern for fake reviews, review platforms started to implement protective measures. One of the most commonly used mechanisms is to allow only "verified buyers" to review offered products and services [10]. Other actions are platform controlled algorithms, which filer out fake reviews [3]. Unfortunately, the line between faked and non-faked reviews is not distinct. Because of the risk to accidentally delete real reviews, there is a controversial discussion about the use of such algorithms [3].

Identified research gaps. Even though platforms apply different measures to react to fake reviews, it remains unclear how these measures impact consumer behavior. It is questionable whether fake review filters increase consumer trust in the review system. Filters might lead to an even higher awareness of counterfeit reviews and thus induce a feeling of mistrust. Additionally, it is of interest in what way such algorithms impact customer satisfaction or the choice of platforms. It seems reasonable that fake review filters affect the attitudes towards the platform, its perceived competence, or the general trust in the service of the platform. Moreover, fake reviews might impact the value of review platforms in the long run. Honest reviews could increase the quality and efficiency of the market [9], while fake reviews undermine these positive effects.

Supplier-related consequences of fake reviews

Current findings. The visibility of an offer depends on the number and the level of its rating [10]. The reason for this is that platforms use algorithms relying on the number of reviews and the evaluation of products to show users the most promising offers. Since fake reviews influence the rating, they impact the visibility of the offered products, too.

Furthermore, the quality perception of the offers depends on fake reviews. By definition, the authors of fake reviews want to deceive platform users and provide inadequate information about the offer's quality [6]. They do so by proving positive fake reviews to improve their quality perceptions 
and negative counterfeit reviews to decrease the quality perception of competitive offers. Nevertheless, sometimes even negative (fake) reviews can have positive effects. Fussy reviews (especially those of low price offerings) can emphasize positive reviews of other reviewers and thus lead to a more favorable evaluation [29].

Finally, against the background of its influences on visibility and quality perceptions, fake reviews can impact the sales of the offerings. Nevertheless, this impact is controversial [4]. The results differ concerning the effects of: the overall rating, the valence of the reviews, and the number of reviews [32]. Concerning the valence, it has been shown that positive fake reviews stimulate and negative fake reviews impair sales. However, it should be noted that firms can suffer from excessive positive fake reviews. Some results suggest an inverted u-shaped relationship between positive fake reviews and sales [3]. The reasoning behind this is that a vast amount of positive ratings casts mistrust. This effect is especially true for weak brands.

Identified research gaps. Apart from the causes, the consequences of fake reviews are determined by product characteristics. In this context, scholars refer to the attributes of search, experience, or credence goods [24]. On the one hand, one can assume that the impact of fake reviews on the perception is higher when individuals can only hardly evaluate offers on their own. On the other hand, if it is hard to evaluate for individuals, they might be concerned with review manipulation, too. This fact can result in a higher skepticism to reviews, which could even spill over to the offering. Due to these unclear effects of fake reviews on sales, it is in dispute whether these are advantageous for firms in the long run. In addition to that, firms raise expectations by improving their ratings by fake reviews, which they are not able to satisfy. This, in turn, might lead to lower customer satisfaction and decreased sales. Future research should test if and under which circumstance these adverse long-term effects occur.

Finally, it might be interesting to analyze customer emotions as an answer to fake reviews. For example, firms may incur customers' wraith by improving their ratings with fake reviews. These emotions might have further negative downstream consequences on the firm's evaluation (i.e., their reputation) as well as on customer behavior (i.e., boycott behavior).

Conclusion. This paper focuses on the causes and effects of fake reviews. The reasons have been differentiated with regard to user- and supplier-oriented perspectives. Concurrent, the consequences were split into recipient-, supplier- and platform-related effects. For each of those areas, we showed central research gaps.

With the outlined framework, this paper systematically collated the so-far highly fragmented research on fake reviews while, furthermore, we addressed each perspective explicitly. Thereby, the specific nature of each dimension is considered. Concurrently, this paper depicts a holistic view of the causes and effects of fake reviews. While our article facilitates the understanding of and access to the research area of fake reviews in total, it further provides useful links to future research. 


\section{REFERENCES}

1. King, R. A., Racherla, P. \& Bush, V. D. (2014). What we know and don't know about online word-of-mouth: A review and synthesis of the literature. Journal of Interactive Marketing, 28(3), 167-183 [in English].

2. Blank, G. \& Reisdorf, B. C. (2012). The participatory web. Information, Communication \& Society, 15(4), 537-554 [in English].

3. Zhuang, M., Cui, G. \& Peng, L. (2018). Manufactured opinions: The effect of manipulating online product reviews. Journal of Business Research, 87, 24-35 [in English].

4. Duan, W., Gu, B. \& Whinston, A. B. (2008). Do online reviews matter? - An empirical investigation of panel data. Decision Support Systems, 45(4), 16 [in English].

5. Proserpio, D. \& Zervas, G. (2017). Online reputation management: Estimating the impact of management responses on consumer reviews. Marketing Science, 36(5), 645 [in English].

6. Lappas, T. (2012). Fake reviews: The malicious perspective, 23-34 [in English].

7. Chevalier, J. A. \& Mayzlin, D. (2006). The effect of word of mouth on sales: Online book reviews. Journal of Marketing Research, 43(3), 54 [in English].

8. Anderson, E. T. \& Simester, D. I. (2014). Reviews without a purchase: Low ratings, loyal customers, and deception. Journal of Marketing Research, 51(3), 69 [in English].

9. Plotkina, D., Munzel, A. \& Pallud, J. (2018). Illusions of truth-Experimental insights into human and algorithmic detections of fake online reviews. Journal of Business Research, in press [in English].

10. Lappas, T., Sabnis, G. \& Valkanas, G. (2016). The impact of fake reviews on online visibility: A vulnerability assessment of the hotel industry. Information Systems Research, 27(4), 61 [in English].

11. Ellson, A. (2018). Times Investigation: A third of TripAdvisor reviews are fake' as cheats buy five stars. The Times 22.09 [Stand: 12.09.2019]. Retrieved from https://www.thetimes.co.uk/article/hotel-and-caf-cheats-are-caught-trying-to-buytripadvisor-stars-027fbcwc8 [in English].

12. Feng, S., Xing, L., Gogar, A. \& Choi, Y. (2012). Distributional footprints of deceptive product reviews. Proceedings of the Sixth International AAAI Conference on Weblogs and Social Media, 98-105 [in English].

13. Ott, M., Choi, Y., Cardie, C. \& Hancock, J. T. (2011). Finding Deceptive Opinion Spam by Any Stretch of the Imagination. Proceedings of the 49th Annual Meeting of the Association for Computational Linguistics, 19 [in English].

14. Choi, S., Mattila, A. S., van Hoof, H. B. \& Quadri-Felitti, D. (2017). The role of power and incentives in inducing fake reviews in the tourism industry. Journal of Travel Research, 56(8), 87 [in English].

15. Jindal, N. \& Liu, B. (2008). Opinion spam and analysis. WSDM, 219 [in English].

16. Ott, M., Cardie, C. \& Hancock, J. (2012). Estimating the prevalence of deception in online review communities. Proceedings of the 21 st international conference on World Wide Web, 201 [in English].

17. Banerjee, A. V. (1992). A Simple Model of Herd Behavior. The Quarterly Journal of Economics, 107(3), 797-817 [in English].

18. Yoo, K.-H. \& Gretzel, U. (2008). Comparison of deceptive and truthful travel reviews, 15, 37-47 [in English]. 
19. Zablocki, A., Schlegelmilch, B. \& Houston, M. J. (2019). How valence, volume and variance of online reviews influence brand attitudes. AMS Review, 9(1-2), 61-77 [in English].

20. Harmon, A. (2004). Amazon glitch unmasks war of reviewers. The New York Times. 14.02. [Stand: 12.09.2019]. Retrieved from https://www.nytimes.com/2004/ 02/14/us/amazon-glitch-unmasks-war-of-reviewers.html [in English].

21. Luca, M. \& Zervas, G. (2013). Fake it Till You Make it: Reputation, Competition, and Yelp Review Fraud. SSRN. Electronic Journal [in English].

22. Mayzlin, D., Dover, Y. \& Chevalier, J. A. (2012). Promotional Reviews: An Empirical Investigation of Online Review Manipulation. SSRN. Electronic Journal [in English].

23. Leary, M. R. \& Kowalski, R. M. (1990). Impression management: A literature review and two-component model. Psychological Bulletin, 107(1), 34-47 [in English].

24. Darby, M. R. \& Karni, E. (1973). Free competition and the optimal amount of fraud. The journal of law \& economics, 16, 67-88 [in English].

25. Gonçalves, H. M., Silva, G. M. \& Martins, T. G. (2018). Motivations for posting online reviews in the hotel industry. Psychology \& Marketing, 35(11), 17 [in English].

26. Petrescu, M., O’Leary, K., Goldring, D. \& Ben Mrad, S. (2018). Incentivized reviews: Promising the moon for a few stars. Journal of Retailing and Consumer Services, 41, 95 [in English].

27. Allard, T., Dunn, L. \& White, K. (2016). Customer empathetic responses toward brands being treated unfairly. Advances in Consumer Research, 44, 80 [in English].

28. Larson, L. R. L. \& Denton, L. T. (2014). eWOM watchdogs: Ego-threatening product domains and the policing of positive online reviews. Psychology \& Marketing, 31(9), 11 [in English].

29. Malbon, J. (2013). Taking Fake Online Consumer Reviews Seriously. Journal of Consumer Policy, 36(2), 57 [in English].

30. Reimer, T. \& Benkenstein, M. (2016). When good WOM hurts and bad WOM gains: The effect of untrustworthy online reviews. Journal of Business Research, 69(12), 5993-6001 [in English].

31. Zhao, Y., Yang, S., Narayan, V. \& Zhao, Y. (2013). Modeling consumer learning from online product reviews. Marketing Science, 32(1), 69 [in English].

32. Mishra, A. \& Sat. The Journal for Decision Makers, 41(3), 22-33 [in English].

The article submitted to editor's office on 12.03.2020.

Фідлер М., Кіслінг М. Фейкові відгуки в маркетингу в електронній торгівлі.

Передмова. Електронна торгівля стала істотним каналом розповсюдження продукиї. Таким чином, відгуки в Інтернеті перетворюються на важливе джерело інформації в процесі прийняття рішення про покупку. Однак, оскільки платформи електронної торгівлі стикаються зі збільшенням кількості маніпульованого контенту, створення фейкових відгуків стало суттєвим викликом для електронної індустрії.

Аналіз останніх досліджень і публікацій. Учені зробили перші спроби аналізу мотивів та причин виникнення так званих фейкових оглядів. Однак всебічного та диферениійованого дослідження з иієї теми бракує.

Метою статті є отримання корисної інформації про причини та наслідки фейкових відгуків, отриманих у межах изього дослідження. Проаналізовано фейкові відгуки, пов'язані з постачальниками та користувачами, досліджено наслідки їх впливу

ISSN 1727-9313. ВІСНИК КНТЕУ. 2020. 
за трьома аспектами: одержувач; постачальник товару чи послуги; платформа огляду. Визначивши ключові прогалини з цього питання, розкрито потенційні сфери майбутнього дослідження з метою полегшення розуміння фейкових відгуків.

Матеріали та методи. Здійснено систематичний огляд літератури серед декількох баз даних та надано рекомендації для подальшого дослідження. Об'єднавши наявні висновки, визначено недоліки у наявних дослідженнях.

Результати дослідження. Розглянуто мотиви та наслідки фейкових відгуків. виділено причини щцодо перспектив, які орієнтовані на користувачів та постачальників. Наслідки поділено на ефекти, пов'язані з одержувачем, постачальником та платформою. Визначено основні недоліки для кожної з ичих сфер.

Висновки. Проаналізовано дослідження щзод маніпулювання електронною торгівлею та різноманітні фейкові відгуки з різних точок зору з метою врахування специфіки кожного аспекту. Розкрито причини та наслідки маніпульованих відгуків в Інтернеті.

Ключові слова: фейкові відгуки, онлайнвідгуки, система рекомендацій в Інтернеті, відгуки про товар, маніпулювання, електронна торгівля. 